\title{
Hypertensive Disorders of Pregnancy - A Life-Long Risk?!
}

\section{Hypertensive Schwangerschaftserkrankungen - Risiko auf Lebenszeit?!}

Authors

Affiliation

\section{E. Schausberger, V. R. Jacobs, G. Bogner, P. Wolfrum-Ristau, T. Fischer}

Universitätsklinik für Frauenheilkunde und Geburtshilfe (OB/GYN) der Salzburger Landesklinken (SALK) \& Paracelsus Medizinische Universität (PMU)

\section{Key words \\ - hypertensive disorders of pregnancy \\ - arterial hypertension \\ - cardiovascular risks \\ - follow-up \\ - prevention}

\section{Schlüsselwörter}

- hypertensive Schwangerschaftserkrankungen

- arterielle Hypertonie

- kardiovaskuläres Risiko

- Follow-up

- Prävention

$\begin{array}{lr}\text { received } & 10.11 .2012 \\ \text { revised } & 17.12 .2012 \\ \text { accepted } & 21.12 .2012\end{array}$

Bibliography

DOI http://dx.doi.org/

10.1055/s-0032-1328172

Geburtsh Frauenheilk 2013; 73 :

47-52 @ Georg Thieme

Verlag KG Stuttgart · New York. ISSN 0016-5751

\section{Correspondence}

\section{Dr. Christiane Elisabeth}

Schausberger, Dr. med. univ.

Universitätsklinik

für Frauenheilkunde

Geburtshilfe und Perinatologie

\& Universitätsklinik für Spezielle

Gynäkologie/Brustzentrum

Müllner Hauptstraße 48

5020 Salzburg

Austria

Christiane.Schausberger@

gmx.at

\section{Abstract \\ $\nabla$}

Background: Arterial hypertension is one of the most important causes of cardiovascular diseases, and the latter are responsible for almost half of the deaths in the industrialised nations. Hypertensive disorders of pregnancy constitute one of the most frequent causes of feto-maternal morbidity and mortality; on the other hand the occurrence of a hypertensive disorder of pregnancy represents a risk for the later development of hypertension and the cardiovascular risks resulting therefrom. The aim of this article is to demonstrate the association of hypertensive disorders of pregnancy with consecutive cardiovascular diseases.

Materials and Methods: Specific selective literature research.

Results: After the occurrence of a hypertensive disorder of pregnancy the relative risks for hypertension are 3.7 (2.70-5.05), for ischaemic heart disease 2.2 (1.86-2.52), for cerebral insult 1.8 (1.45-2.27) and for mortality resulting from cardiovascular causes $1.5(1.05-2.14)$ and are thus significant. According to a recent study $56 \%$ of internal specialists and $23 \%$ of gynecologists do not know about the association of preeclampsia with ischemic heart disease, $48 \%$ and $38 \%$ respectively are not aware of the link with stroke and $79 \%$ and $77 \%$ respectively are not aware of the association with a reduced life expectancy after preeclampsia. The presence of hypertension is not known by many of the patients, merely $28-38 \%$ receive an appropriate therapy.

Conclusion: Adequate follow-up after hypertensive disorders of pregnancy and the early recognition of and therapy for hypertension represent the cornerstones in the prevention of late cardiovascular sequelae. General practitioners, specialist for internal medicine and gynaecologists have a special responsibility with regard to the reduction of later complications.

\section{Zusammenfassung \\ $\nabla$}

Hintergrund: Die arterielle Hypertonie gehört zu den wichtigsten Ursachen für kardiovaskuläre Erkrankungen, letztere sind für fast die Hälfte aller Todesfälle in Industrieländern verantwortlich. Hypertensive Schwangerschaftserkrankungen gehören zum einen zu den häufigsten Ursachen für fetomaternale Morbidität und Mortalität, zum anderen zeigt das Auftreten einer hypertensiven Schwangerschaftserkrankung ein Risiko für eine später auftretende Hypertonie und das daraus resultierende kardiovaskuläre Risiko auf. Ziel dieses Artikels ist es, die Assoziation von hypertensiven Schwangerschaftserkrankungen mit später auftretenden kardiovaskulären Erkrankungen darzustellen.

Material und Methodik: Spezifisch selektive Literaturrecherche.

Ergebnisse: Nach Auftreten einer hypertensiven Schwangerschaftserkrankung sind die relativen Risiken für eine Hypertonie 3,7 (2,70-5,05), für eine ischämische Herzerkrankung 2,2 (1,86$2,52)$, für einen zerebralen Insult $1,8(1,45-2,27)$ und für die kardiovaskulär bedingte Mortalität $1,5(1,05-2,14)$ und damit signifikant. 56\% der Internisten und 23\% der Gynäkologen kennen laut einer aktuellen Studie die Assoziation mit ischämischen Herzerkrankungen nicht, 48 bzw. 38\% nicht die Assoziation mit späteren Insulten und 79 bzw. 77\% nicht die Assoziation mit einer verminderten Lebenserwartung nach Präeklampsie. Das Vorliegen einer Hypertonie ist vielen Betroffenen nicht bekannt, $28-38 \%$ erhalten eine ausreichende Therapie.

Schlussfolgerung: Adäquate Nachsorge nach hypertensiven Schwangerschaftserkrankungen sowie die frühzeitige Erkennung und adäquate Therapie einer Hypertonie stellen die Eckpfeiler in der Prävention kardiovaskulärer Spätfolgen dar. Hausarzt, Internist und Frauenarzt sind für die 
Reduktion späterer Komplikationen von wesentlicher Bedeutung.

\section{Introduction}

The group of cardiovascular diseases is the most frequent cause of death in the industrialised nations. One of the major reasons for death due to cardiovascular problems is arterial hypertension. About one quarter of the world's population suffers from arterial hypertension. Although on the whole men and women are equally affected, postmenopausal women suffer increasingly more often from hypertension than men [1].

Early recognition of and therapy for arterial hypertension can markedly reduce the long-term cardiovascular sequelae. Furthermore, prevention in the form of lifestyle changes can delay the occurrence of hypertension and reduce its severity.

It is important that the occurrence of a hypertensive disorder of pregnancy - and this includes, among others, hypertension induced by pregnancy, preeclampsia as well as HELLP syndrome at a young age can be considered as a relevant indication for the later development of chronic hypertension [2]. If this knowledge would be consequently implemented in strategies for early detection and prevention, the cardiovascular risks and the subsequent cardiovascular mortality could be reduced for the afflicted women.

The aim of the present review is to help reduce the morbidity and mortality for women who have suffered from hypertensive disorders of pregnancy by demonstrating in principle the relationships between hypertensive disorders of pregnancy with later cardiovascular diseases and by emphasising the significance of an adequate follow-up.

\section{Materials and Methods}

$\nabla$

Selective literature searches (Medline, Cochrane Library) were carried out on the basis of the key words "pregnancy" and "hypertensive", individually combined with the further key words "preeclampsia”, "hypertension”, “cardiovascular", "mortality", "risk" and "prevention" and with exclusion of those references that investigated the pathogenesis of hypertensive diseases of pregnancy. Also included were the cited reference articles as well as basic references and national as well as international guidelines.

\section{Arterial Hypertension and Women}

$\nabla$

Arterial hypertension is one of the most important risk factors for morbidity and mortality due to cardiovascular problems. $26.4 \%$ of the world population, more or less equally distributed between men and women suffer, from arterial hypertension: $26.1 \%$ of all women and $26.6 \%(26.0-27.2 \%)$ of all men [3]. However, there are age-dependent and gender-specific differences. Up to 45 years of age men suffer more frequently from hypertension than women, between the ages of 46 and 65 years the gender-specific difference is almost non-existent, from 65 years onwards women suffer more than men from elevated blood pressure [1]. Due to demographic developments and the increasing average age of the central European population an increase in the number of afflicted women is to be expected in the future [4].
Cardiovascular sequelae of hypertension such as myocardial infarction, heart failure and cerebral insult constitute the main causes of all deaths in the industrialised nations. In Germany cardiovascular causes are responsible for $45.1 \%$ of all deaths among women. In comparison $26.7 \%$ of all deaths among women are due to cancer [5]. International data show that therapy for arterial hypertension is often inadequate. This applies especially for elderly women. The rates for guideline-conform therapy for hypertension in men and women are, according to age groups $(\mathrm{p}<0.01)$ [6]:

< 60 years: $38 \%$ for men and women

- 60-79 years: $36 \%$ for men vs. $29 \%$ for women

$\checkmark \geq 80$ years: $38 \%$ for men vs. $23 \%$ for women

Thus arterial hypertension together with its clinical consequences is of enormous health-care political importance. Primary prevention of hypertension, early diagnosis of hypertension and adequate non-drug as well as pharmacological therapies are decisive cornerstones for the prevention of morbidity and mortality due to cardiovascular problems.

Since there is a direct association between hypertensive disorders of pregnancy and a later cardiovascular risk, the case histories and courses of previous pregnancies should be an essential part of general and internal medical examinations. Pregnancy is so to speak a general medical stress test and should thus be considered as a suitable medical window for the future.

\section{Hypertensive Disorders of Pregnancy \\ $\nabla$}

Among the hypertensive disorders of pregnancy - including hypertension induced by pregnancy, preeclampsia and HELLP syndrome - there are various clinical pictures with in part widely differing clinical courses and severities ( Table $\mathbf{1}$ ).

The incidence of hypertensive disorders of pregnancy varies in the literature and according to recent data amounts to 6-8\% [79]. Since the incidence increases with increasing maternal age, body mass index and associated accompanying diseases, an increase must be expected in the course of time due to the demographic developments. In central Europe hypertensive disorders of pregnancy represent one of the three most frequent causes of death among pregnant women after haemorrhages and thromboembolisms $[10,11]$.

Preeclampsia is of particular importance as it is to a large extent responsible not only for increased maternal but also for increased perinatal morbidity and mortality. The frequency of preeclampsia including the HELLP syndrome, which is considered to be a variant of preeclampsia, amounts to $2-4 \%$. Primiparous women are afflicted about 2- to 3-times more frequently than multiparous women [12].

Possible complications of preeclampsia are eclamptic seizures or the occurrence of a cerebral insult.

Cerebral insults are very rare and can be both haemorrhagic (92.6\%) as well as ischaemic (7.4\%). In such cases the systolic blood pressure is of more significance than the diastolic value. A cerebral insult is not to be expected below a systolic blood pressure of $155 \mathrm{mmHg}$, according to the literature most insults occur at a systolic value above $160 \mathrm{mmHg}$ [13]. According to the ACOG 
Table 1 Classification of the hypertensive disorders of pregnancy (data taken from DGGG guideline, stand 2010 [15]).

\begin{tabular}{|c|c|c|}
\hline Gestational hypertension & $\begin{array}{l}R R \geq 140 / 90 \mathrm{mmHg} \text { after } 20 \text { th week of pregnancy } \\
\text { in patient without pre-existing hypertension }\end{array}$ & $\begin{array}{l}\text { within } 12 \text { weeks return to normotensive blood pressure values, } \\
\text { no proteinuria } \geq 300 \mathrm{mg} / 24 \mathrm{~h}\end{array}$ \\
\hline Preeclampsia & $\begin{array}{l}\mathrm{RR} \geq 140 / 90 \mathrm{mmHg} \text { after } 20 \text { the week of pregnancy } \\
\text { in patient without pre-existing hypertension } \\
\text { plus proteinuria } \geq 300 \mathrm{mg} \text { in } 24 \text {-h urine }\end{array}$ & \\
\hline HELLP syndrome & $\begin{array}{l}\text { haemolysis } \\
\text { elevated liver enzymes } \\
\text { low platelets }(<100,000 / \mu \mathrm{L})\end{array}$ & $\begin{array}{l}\text { special form of preeclampsia } \\
\text { hypertension and proteinuria may be lacking }\end{array}$ \\
\hline Eclampsia & tonic-clonic seizures in cases of preeclampsia & hypertension and proteinuria may be lacking \\
\hline Pre-existing hypertension & $\begin{array}{l}R R \geq 140 / 90 \mathrm{mmHg} \text { pre-conception or before 20th week } \\
\text { of pregnancy }\end{array}$ & hypertension persisting beyond 12 weeks post partum \\
\hline $\begin{array}{l}\text { Preeclampsia superimposed } \\
\text { on chronic hypertension }\end{array}$ & $\begin{array}{l}R R \geq 140 / 90 \mathrm{mmHg} \text { pre-conception or before } 20 \text { th week } \\
\text { of pregnancy plus de-novo proteinuria } \geq 300 \mathrm{mg} \text { in } 24 \text {-h urine } \\
\text { or } \\
R R \geq 140 / 90 \mathrm{mmHg} \text { and proteinuria pre-conception of before } \\
\text { 20th week of pregnancy and sudden elevation of hypertension } \\
\text { or proteinuria } \geq 20 \text { th week of pregnancy }\end{array}$ & hypertension persisting beyond 12 weeks post partum \\
\hline
\end{tabular}

systolic blood pressure values of more than $160 \mathrm{mmHg}$ should be reduced by drug therapy [14]. The guidelines of the DGGG state that systolic blood pressures above $170 \mathrm{mmHg}$ should be reduced by drug therapy and - in cases with pre-existing vascular diseases - even for systolic values above $160 \mathrm{mmHg}$ [15]. The maternal mortality amounts to $53.6 \%$ after an insult, and the morbidity is high among the survivors. In the literature merely $11 \%$ of the women remain without significant late sequelae after a cerebral insult in the course of hypertensive disorders of pregnancy [13]. The full clinical picture of a hypertensive disorder of pregnancy can develop during the antepartal, intrapartal and even during the first postpartal days. In up to 30\% a HELLP syndrome can show first manifestations in the postpartal period [16], an eclamptic seizure in up to 44\% [17]. For this reason maternal monitoring and therapy are also mandatory in the lying-in period after delivery.

Foetal consequences consist on the one hand of growth retardation and an increased rate of IUFT due to placentation disorders and on the other hand the associated premature birth [18]. Thus, management of preeclampsia is always a compromise between pregnancy prolongation and delivery, between foetus and mother [19].

\section{Association of Hypertensive Disorders of Pregnancy with Later Hypertension and Cardiovascular Risks}

After the occurrence of a hypertensive disorder of pregnancy there is not only a demonstrated increased risk for a recurrence in subsequent pregnancies [20] but also - staggered in time - a significantly higher risk for cardiovascular diseases than in a comparable collective of women without hypertensive disorders of pregnancy $[21,22]$.

The question as to how the increased cardiovascular risk arises after a hypertensive disorder of pregnancy has not been answered unequivocally. Is the endothelial dysfunction a common risk factor not only for pregnancy-induced high blood pressure disease but also for later cardiovascular diseases or is possibly a change first induced or potentiated by the occurrence of the hypertensive disorder of pregnancy which is ultimately partially or wholly responsible for the markedly increased risk for the afflicted women?

At present the former hypothesis is rather more favoured, i.e., it appears that, even before the onset of pregnancy, some young women have a predisposition that can lead to a preeclampsia and later, after a symptom-free period, favour the development of arterial hypertension and cardiovascular diseases.

A hint for such a predisposition in the first line is the presence of elevated, albeit still guideline-conform as normotensive, systolic and diastolic blood pressure values prior to conception, higher than in those in women without such a predisposition [23]. The existence of higher levels of triglycerides, LDL and an unfavourable HDL/LDL ratio does not appear to represent a further hint for a predisposition for hypertensive disorders of pregnancy and cardiovascular diseases in later life, but is rather a coincidence with a higher BMI ( Table 2) [23].

After the occurrence of preeclampsia, in comparison to women without hypertensive disorders of pregnancy, there is a markedly higher risk to develop arterial hypertension, to suffer from an ischaemic heart disease with or without lethal outcomes, to experience an ischaemic or haemorrhagic cerebral insult, or to be afflicted by a thromboembolic incident ( Table 3) [21,24,25].

Table 2 Pre-conceptional differences between women with and without subsequent hypertensive disorders of pregnancy (data taken from Romundstad et al. $2010[23])$.

\begin{tabular}{|lccc} 
& $\begin{array}{l}\text { No hypertensive disorder } \\
\text { of pregnancy } \\
\text { Average BMI }\left(\mathrm{kg} / \mathrm{m}^{2}\right)\end{array}$ & $\begin{array}{l}\text { Hypertensive disorder } \\
\text { of pregnancy }\end{array}$ & $\begin{array}{l}\text { Mean difference } \\
\text { (adjusted) }\end{array}$ \\
\hline Average systolic blood pressure $(\mathrm{mmHg})$ & 117 & 126 & $0.1(0.5-1.1)$ \\
\hline Average diastolic blood pressure $(\mathrm{mmHg})$ & 74 & 81 & $8.2(4.7-7.8)$ \\
\hline Antihypertensive drugs in case history $(\%)$ & 1 & $3.5(2.4-4.6)$ & no data
\end{tabular}


Table 3 Increase of risk for cardiovascular diseases after preeclampsia $(R R=$ rel. risk) (data taken from Bellamy et al. 2007 [25]).

\begin{tabular}{|lll|}
\hline & $\begin{array}{l}\text { RR after preeclampsia } \\
\text { (95\% confidence } \\
\text { interval) }\end{array}$ & $\begin{array}{l}\text { Average follow-up } \\
\text { time (in years) }\end{array}$ \\
\hline $\begin{array}{l}\text { Arterial hypertension } \\
\text { Ischaemic heart }\end{array}$ & $2.70(2.70-5.05)$ & 14.1 \\
\hline $\begin{array}{l}\text { disease } \\
\text { Cerebral insult }\end{array}$ & $1.81(1.46-2.52)$ & 11.7 \\
\hline $\begin{array}{l}\text { Thromboembolic } \\
\text { event }\end{array}$ & $1.79(1.37-2.33)$ & 10.4 \\
\hline
\end{tabular}

In addition, there is an inverse correlation between an early manifestation of preeclampsia and the probability of a later hypertension or, respectively, a later cardiovascular risk - in other words: the earlier (referred to weeks of pregnancy) the preeclampsia occurs, the higher is the later risk of cardiovascular disease [25].

The severity of preeclampsia as well as the repeated occurrence of preeclampsia in several pregnancies also correlate with the cardiovascular risk $[24,25,48,49]$ : the risk for an ischaemic heart disease after the occurrence of preeclampsia is increased by a factor of 2.2 in comparison to healthy women. After an early manifestation of preeclampsia before the 37th week of pregnancy the risk for an ischaemic heart disease is even increased by a factor of 7.7 in comparison to healthy women (Table 4). The risk to suffer from a cerebral insult is increased by a factor of 5.1 after occurrence of an early preeclampsia before the 37th week of pregnancy in comparison to that for women who develop preeclampsia after the 37th week of pregnancy. In cases of severe preeclampsia the risk for a venous thromboembolism increases by a factor of 2.3 in comparison to cases of mild preeclampsia.

The study situation with regard to cardiovascular risk after gestational hypertension without preeclampsia is less homogeneous than that for the cardiovascular risk after preeclampsia [25-27]. But even here a significant relationship with an increased incidence of later arterial hypertension can be demonstrated: relative risk 5.3 (4.90-5.75). Furthermore, there is an unambiguous indication for a more frequent occurrence of diabetes mellitus after gestational hypertension and preeclampsia [26].

The mortality after preeclampsia is increased by a factor of 1.49 (1.05-2.12) or, respectively by a factor of 2.71 (1.99-3.68) after early preeclampsia (<37th week of pregnancy). After a hypertensive disorder of pregnancy an increased mortality due to cancer

Table 4 Ischaemic heart disease after preeclampsia in dependence on time of onset and severity of the preeclampsia $(R R=$ rel. risk) (data taken from Bellamy et al. 2007 [25])

\begin{tabular}{|l|l|}
\hline & $\begin{array}{l}\text { Ischaemic heart disease } \\
\text { relative risk } \\
\text { (95\% confidence interval) }\end{array}$ \\
\hline $\begin{array}{l}\text { RR after preeclampsia } \\
\text { (95\% confidence interval) }\end{array}$ & $2.16(1.86-2.52)$ \\
\hline $\begin{array}{l}\text { RR after preeclampsia <37th week } \\
\text { of pregnancy (95\% confidence interval) }\end{array}$ & $7.71(4,4-13.52)$ \\
\hline $\begin{array}{l}\text { RR after severe preeclampsia } \\
\text { (95\% confidence interval) }\end{array}$ & $2.86(2.25-3.65)$ \\
\hline $\begin{array}{l}\text { RR after mild preeclampsia } \\
\text { (95\% confidence interval) }\end{array}$ & $1.92(1.65-2.24)$ \\
\hline
\end{tabular}

(all cancers) as well as an increased breast cancer-associated mortality can be excluded. The increase in mortality can thus be attributed mainly to cardiovascular causes $[25,28]$.

\section{Medical Knowledge with Regard to Late Cardiovascular Manifestations after Hypertensive Disorders of Pregnancy $\nabla$}

A recent study was concerned with the knowledge about the relationships between hypertensive disorders of pregnancy and later cardiovascular risks and came to the following results: 56\% of the internal medicine specialists and $23 \%$ of the gynaecologists were not, or were only insufficiently, aware of the association of preeclampsia with later ischaemic heart disease, $48 \%$ of the internal medicine specialists and $38 \%$ of the gynaecologists did not know about the association with later stroke and $79 \%$ and, respectively, $77 \%$ about the association with a lower life expectancy [29].

\section{Lying-in and Postpartum Course \\ $\nabla$}

In most women with hypertensive disorders of pregnancy the elevated blood pressure normalises within a few days after birth, in cases of pure gestational hypertension on average after 6 days, in cases of preeclampsia after 16 days [30]. However, this is not the case in about $5 \%$ of all patients with pregnancy-associated hypertensive diseases, in other words these patients remain hypertensive. It may be assumed that the major proportion of these women were suffering from an undiagnosed chronic hypertension already prior to the pregnancy. On account of the fall in blood pressure during the first half of pregnancy a pre-existing hypertension is at first often not recognised.

Not only does the blood pressure mostly return to normal rapidly postpartum but also the laboratory parameters and - if present the patient's subjective complaints normalise. Subclinical changes, however, remain and above all for women afflicted with hypertensive disorders of pregnancy in common there is the higher cardiovascular risk.

Comprehensive information for the patient before release of the afflicted women from the hospital is very important. The value of the transmission of information about the nature and severity of the hypertensive disorder of pregnancy to the patient's subsequently responsible gynaecologist, general practitioner or internist should be emphasised with the aims of early detection of a later hypertension and its adequate therapy in order to reduce the cardiovascular risks.

\section{Follow-up: Primary Prophylaxis, Diagnostics and Therapy}

A renewed occurrence of arterial hypertension should be diagnosed as early as possible in order to avoid end organ damage. For this purpose the patients are recommended to undergo an annual outpatient 24-h blood pressure control [31]. In addition an outpatient, protocolled self-control of blood pressure can be considered. Upon confirmation of hypertension the decision concerning type and intensity of the antihypertensive therapy is made in consideration of the cardiovascular risk and depending on the severity of the hypertension. 
Monitoring of renal parameters until normalisation and thereafter when signs of renal function disorders are present is also strongly recommended. This includes the exclusion of the persisting proteinuria and microalbuminuria (24-hour urine collection) as well as measurement of serum creatinine [32]. In particular, a persisting or recurring microalbuminuria is the sign for an up to $50 \%$ increased cardiovascular risk [33]. Even in non-diabetic and normotensive patients a mild microalbuminuria below the actual cut-off value constitutes a cardiovascular risk factor, furthermore it is an early marker for later kidney diseases in previously preeclamptic women. In comparison to women after uncomplicated pregnancies, the frequency of a microalbuminuria is increased by a factor of 4-8 in women after preeclampsia [34]. The regular performance of an oral glucose tolerance test after the occurrence of a hypertensive disorder of pregnancy cannot uniformly be recommended on the basis of the current state of knowledge. However, since the risk of type 2 diabetes is increased by a factor of 3-4 not only after gestational hypertension but also after preeclampsia [26] and the fact that diabetes mellitus further increases the cardiovascular risks, the performance of this screening examination may be considered [50]. Factors that are suspicious for the existence of a diabetic metabolic situation should be considered and, if present, should in every case result in the performance of an oral glucose tolerance test.

It is sufficiently well known that numerous primary prophylactic, so-called lifestyle measures, have been demonstrated to hinder hypertension [35]. These include healthy nutrition, weight reduction in cases of high BMI $[36,37]$, regular physical exercise [38], reduction of an excessive alcohol consumption [39] as well as cessation of smoking or other forms of tobacco consumption [35]. Support of the patient's self responsibility is an essential but often difficult to realise point of intervention.

As secondary prophylaxis the timely and adequate initiation of an antihypertensive therapy can markedly reduce the subsequent effects of high blood pressure on the cardiovascular system [40]. Reduction of the diastolic blood pressure by merely $1 \mathrm{mmHg}$, for example, leads to a $2-3 \%$ reduced rate of myocardial infarction. Reduction of the blood pressure by $5-6 \mathrm{mmHg}$ can reduce the insult rate within 5 years by $42 \%$ [41]. Cofactors for subsequent cardiovascular diseases besides hypertension, such as dyslipidosis or diabetes mellitus, must each be treated accordingly [42]. The exploitation of all therapeutic options beginning with lifestyle changes through to polypharmacological treatment [43] is an essential factor.

That by far not all patients with hypertension are recognised as such and thus especially are not receiving an adequate therapy has been demonstrated by a comparative study in Germany: the hypertension is known in 59\% of all hypertensive women aged between 35 and 64 years in Germany, it is being treated in $47 \%$ and merely $63 \%$ of all hypertensive women under treatment are receiving an adequate therapy. Thus, altogether only $29 \%$ of all women with hypertension are receiving an appropriate treatment [44]. One reason for the low recognition rate of hypertension in the population may be the low degree of awareness about screening examinations. Thus, for example, for all people over the age of 35 years in Germany the statutory health insurances cover the costs for a health check-up ("Check-Up 35+") [45] every 2 years, but this is much too seldom utilised (24.7\% of all women). The participation in gynaecological screening programmes such as the nation-wide mammography screening is currently stated as being $54 \%$ [46], the cervical cancer screening programmes have a participation of on average $36-51 \%$ [47]. Thus, the respon- sible gynaecologists have the possibility and the duty to inform their patients of the significance of follow-up after hypertensive diseases of pregnancy and to implement it in close cooperation with the patient's general practitioner and/or internist. We once again emphasize the need to provide the patient with comprehensive information about the risks of hypertension and the associated cardiovascular consequences as well as about the possibilities for prophylactic and, if necessary, therapeutic interventions.

\section{Conclusion \\ $\nabla$}

Arterial hypertension is one of the most important risk factors for morbidity and mortality due to cardiovascular causes, even so only one quarter to one third of all women with hypertension are receiving an adequate therapy.

On the one hand hypertensive disorders of pregnancy lead to direct foeto-maternal consequences and on the other hand there is a significant relationship with a later developing arterial hypertension, with cardiovascular morbidity and mortality.

The appropriate follow-up of women after hypertensive disorders of pregnancy leads to the early diagnosis of a later arterial hypertension; cardiovascular late sequelae can be markedly reduced by an early and adequate therapy. By means of primary and secondary prophylactic intervention post partum the occurrence of arterial hypertension can be delayed and in the best case completely avoided.

\section{Conflict of Interest \\ $\nabla$}

None.

\section{References}

1 Roger VL, Go AS, Lloyd-Jones DM et al. Heart disease and stroke statistics - 2011 update: a report from the American Heart Association. Circulation 2011; 123: e18-e209

2 Sibai BM, el-Nazer A, Gonzalez-Ruiz A. Severe preeclampsia-eclampsia in young primigravid women: subsequent pregnancy outcome and remote prognosis. Am J Obstet Gynecol 1986; 155: 1011-1016

3 Kearney PM, Whelton M, Reynolds $K$ et al. Global burden of hypertension: analysis of worldwide data. Lancet 2005; 365: 217-223

4 Billmann $M-K$, Rath W, Beinder E. Schwangerschaften bei erhöhtem mütterlichen Alter: Ergebnisse aus Zürich und Literaturübersicht. Geburtsh Frauenheilk 2010; 70: 273-280

5 Gesundheitsberichterstattung des Bundes. Gesundheit in Deutschland 2006: Häufige Todesursachen. Internet: www.gbe-bund.de/gbe10/ abrechnung.prc_abr_test_logon?p_aid=6507540\&p_uid=gasts\& p_sprache=D\&p_knoten=FID\&p_suchstring $=10565 \#$ fid10542; last access: 27.08.2012

6 Lloyd-Jones DM, Evans JC, Levy D. Hypertension in adults across the age spectrum: current outcomes and control in the community. JAMA 2005; 294: 466-472

7 National High Blood Pressure Education Program Working Group. Report of the National High Blood Pressure Education Program Working Group on high blood pressure in pregnancy. Am J Obstet Gynecol 2000; 183: S1-S22

8 Walker JJ. Pre-eclampsia. Lancet 2000; 356: 1260-1265

9 Koonin LM, MacKay AP, Berg CJ et al. Pregnancy-related mortality surveillance-United States, 1987-1990. MMWR CDC Surveill Summ 1997; 46: 17-36

10 Fässler M, Zimmermann R, QuackLötscher KC. Maternal mortality in Switzerland 1995-2004. Swiss Med Wkly 2010; 140: 25-30

11 Verlohren S, Dudenhausen JW. Schwangerschaftshypertonie. Präeklampsie und hypertensive Schwangerschaftserkrankungen. Geburtsh Frauenheilk 2012; 72: 496-498 
12 Magnussen EB, Vatten LJ, Smith GD et al. Hypertensive disorders in pregnancy and subsequently measured cardiovascular risk factors. Obstet Gynecol 2009; 114: 961-970

13 Martin JN, Thigpen BD, Moore RC et al. Stroke and severe preeclampsia and eclampsia: a paradigm shift focusing on systolic blood pressure. Obstet Gynecol 2005; 10: 246-254

14 Committee on Obstetric Practice. Committee Opinion no. 514: emergent therapy for acute-onset, severe hypertension with preeclampsia or eclampsia. Obstet Gynecol 2011; 118: 1465-1468

15 Deutsche Gesellschaft für Gynäkologie und Geburtshilfe (DGGG). Diagnostik und Therapie hypertensiver Schwangerschaftserkrankungen. AWMF 015/018 (S2). Internet: www.dggg.de/fileadmin/public_docs/ Leitlinien/3-3-4-sws-hochdruck-2010.pdf; last access: 27.08.2012

16 Rath W, Faridi A, Dudenhausen JW. HELLP syndrome. J Perinat Med 2000; 28: 249-260

17 Sibai BM. Diagnosis, prevention, and management of eclampsia. Obstet Gynecol 2005; 105: 402-410

18 Shapiro-Mendoza CK, Tomashek KM, Kotelchuck M et al. Effect of latepreterm birth and maternal medical conditions on newborn morbidity risk. Pediatrics 2008; 121: e223-e232

19 Backes CH, Markham K, Moorehead P et al. Maternal preeclampsia and neonatal outcomes. J Pregnancy 2011; 2011: 214365

20 Zhao HY, Chen XW, Niu JQ et al. [History of pregnancy induced hypertension is linked with increased risk of cardio-cerebral vascular events]. Zhonghua Xin Xue Guan Bing Za Zhi 2012; 40: 645-651

21 Niesert S. Obstetric prognosis after pre-eclampsia, eclampsia or HELLP syndrome. Geburtsh Frauenheilk 1996; 56: 93-96

22 Funai EF, Friedlander $Y$, Paltiel $O$ et al. Long-term mortality after preeclampsia. Epidemiology 2005; 16: 206-215

23 Romundstad PR, Magnussen EB, Smith GD et al. Hypertension in pregnancy and later cardiovascular risk: common antecedents? Circulation 2010; 122: 579-584

24 Steegers EA, von Dadelszen P, Duvekot JJ et al. Pre-eclampsia. Lancet 2010; 376: 631-644

25 Bellamy L, Casas JP, Hingorani AD et al. Pre-eclampsia and risk of cardiovascular disease and cancer in later life: systematic review and metaanalysis. BMJ 2007; 335: 974

26 Lykke JA, Langhoff-Roos J, Sibai BM et al. Hypertensive pregnancy disorders and subsequent cardiovascular morbidity and type 2 diabetes mellitus in the mother. Hypertension 2009; 53: 944-951

27 Fraser A, Nelson SM, Macdonald-Wallis C et al. Associations of pregnancy complications with calculated cardiovascular disease risk and cardiovascular risk factors in middle age: the Avon Longitudinal Study of Parents and Children. Circulation 2012; 125: 1367-1380

28 Irgens HU, Reisaeter L, Irgens LM et al. Long term mortality of mothers and fathers after pre-eclampsia: population based cohort study. BMJ 2001; 323: 1213-1217

29 Young B, Hacker MR, Rana S. Physicians' knowledge of future vascular disease in women with preeclampsia. Hypertens Pregnancy 2012; 31: $50-58$

30 Ferrazzani S, De Carolis S, Pomini F et al. The duration of hypertension in the puerperium of preeclamptic women: relationship with renal impairment and week of delivery. Am J Obstet Gynecol 1994; 171: 506512

31 Fischer T, Langenfeld $M$. Nachbetreuung von Präeklampsie-Patientinnen. In: Rath W, Heilmann L, eds. Schwangerschaftshochdruck. 1st ed. Stuttgart: Wissenschaftliche Verlagsgesellschaft; 2002: 279-299

32 Fischer T. Nierenerkrankungen und Schwangerschaft. In: Rath $\mathrm{W}$, Gembruch U, Schmidt S, eds. Geburtshilfe und Perinatalmedizin. Stuttgart: Thieme; 2010: 429-440

33 Chobanian A, Bakris GL, Black $H$ et al. Evaluation, and treatment of high blood pressure. Seventh report of the Joint National Committee on Prevention, Detection. Hypertension 2003; 42: 1206-1252
34 McDonald SD, Han Z, Walsh MW et al. Kidney disease after preeclampsia: a systematic review and meta-analysis. Am J Kidney Dis 2010; 55 : 1026-1039

35 Mosca L, Appel LJ, Benjamin EJ et al. Evidence-based guidelines for cardiovascular disease prevention in women. Circulation 2004; 109: 672693

36 Mulrow CD, Chiquette E, Angel L et al. Dieting to reduce body weight for controlling hypertension in adults. Cochrane Database Syst Rev 2000; 2: CD000484

37 Hypertension Prevention Collaborative Research Group. Effects of weight loss and sodium reduction intervention on blood pressure and hypertension incidence in overweight people with high-normal blood pressure. The Trials of Hypertension Prevention, phase II. Arch Intern Med 1997; 157: 657-667

38 Whelton SP, Chin A, Xin X et al. Effect of aerobic exercise on blood pressure: a meta-analysis of randomized, controlled trials. Ann Intern Med 2002; 136: 493-503

39 Xin X, He J, Frontini MG et al. Effects of alcohol reduction on blood pressure: a meta-analysis of randomized controlled trials. Hypertension 2001; 38: 1112-1117

40 Kostis JB, Davis BR, Cutler J et al.; SHEP Cooperative Research Group. Prevention of heart failure by antihypertensive drug treatment in older persons with isolated systolic hypertension. JAMA 1997; 278: 212-216

41 Fischer T, Schmieder RE, Aepfelbacher FC et al. Antihypertensive Therapy in hypertensive postmenopausal Women. In: Messerli FH, Aepfelbacher FC, eds. Hypertension in postmenopausal Women. New York: Marcel Dekker; 1996: 241-267

42 Mosca L, Appel LJ, Benjamin EJ et al. Summary of the American Heart Association's evidence-based guidelines for cardiovascular disease prevention in women. Arterioscler Thromb Vasc Biol 2004; 24: 394396

43 Janhsen $K$, Strube H, Starker A. Gesundheitsberichterstattung des Bundes, Heft 43: Hypertonie. Berlin: Robert-Koch-Institut; 2008. Internet: www.gbe-bund.de/gbe10/ergebnisse.prc_pruef_verweise?p_uid=gast \&p_aid=12335544\&p_fid=11737\&p_ftyp=TXT\&p_pspkz=D\&p_sspkz= \&p_wsp=\&p_vtrau $=4 \& p \_h l p \_n r=\&$ sprache $=D \& p \_s p r a c h k z=D \& p \_l f d$ $\mathrm{nr}=44 \&$ p_news $=\&$ p_modus=2\&p_window=\&p_janein=J; last access: 27.08.2012

44 Wolf-Maier K, Cooper RS, Kramer H et al. Hypertension treatment and control in five European countries, Canada, and the United States. Hypertension 2004; 43: 10-17

45 Allgemeine Ortskrankenkasse (AOK). Check up 35. Internet: www.aok. de/bundesweit/gesundheit/vorsorge-praevention-gesundheitscheck28014.php; last access: 27.08.2012

46 Kooperationsgemeinschaft Mammographie. Pressemitteilung: Deutsches Mammographie-Screening-Programm ist erfolgreich. Internet: www.mammo-programm.de/presse/archiv-meldungen-details.php? id=124; last access: 27.08 .2012

47 Klug S, Blettner M. Zervixkarzinom, HPV-Infektion und Screening. Dtsch Arztebl 2003; 100: A132-A136

48 Tallarek A-C, Huppertz B, Stepan H. Preeclampsia - aetiology, current diagnostics and clinical management, new therapy Options and future perspectives. Geburtsh Frauenheilk 2012; 72: 1107-1116

49 Elsen C, Rivas-Echeverría C, Sahland K et al. Vitamins E, A and $B_{2}$ as possible risk factors for preeclampsia - under consideration of the PROPER study ("Prevention of preeclampsia by high-dose riboflavin supplementation"). Geburtsh Frauenheilk 2012; 72: 846-852

50 Reeske A, Zeeb H, Razum $O$ et al. Differences in the incidence of gestational diabetes between women of Turkish and German origin: an analysis of health insurance data from a statutory health insurance in Berlin, Germany (AOK), 2005-2007. Geburtsh Frauenheilk 2012; 72: 305310

Deutschsprachige Zusatzinformationen online abrufbar unter: www.thieme-connect.de/ejournals/toc/gebfra. 